\title{
Centurionowie Cezara: elita legionów czy kreacja literacka?
}

\begin{abstract}
Abstrakt: Jedną z charakterystycznych cech narracji Cezara poświęconej toczonym przez niego wojnom jest eksponowanie zasług centurionów. Rodzi to pytanie, z jakiego powodu promował akurat tę kategorię żołnierzy i czy w świetle analizy źródłowej ich dokonania bojowe mogą zostać uznane za wiarygodne. Autor podjął próbę zestawienia informacji zawartych w zachowanych przekazach, starając się nie tylko znaleźć potwierdzenie opisów Cezara w kontekście wzrostu znaczenia centurionów w I wieku przed Chr., lecz także uzyskać odpowiedź dotyczącą możliwego powodu zastosowania tego typu zabiegu literackiego. Centurionowie uchodzą za prawdziwy symbol cezariańskiej armii, dlatego temat ten ma istotne znaczenie z punktu widzenia rekonstrukcji stosunków wewnętrznych panujących w legionach ówczesnego prokonsula.
\end{abstract}

Słowa kluczowe: Cezar, centurionowie, armia rzymska, republika rzymska

Studia prowadzone nad okolicznościami powstania, treścią oraz literackim i społecznym kontekstem funkcjonowania dzieł składających się na Corpus Caesarianum mają wieloletnią tradycję, podobnie jak badania poświęcone republikańskiej armii rzymskiej, a jednak wciąż próżno szukać kompleksowego studium poświęconego cezariańskim centurionom. Mimo świadomości daleko idącego stylizowania opisów bitew przez Gajusza Juliusza Cezara i jego naśladowców, podobnie jak przebiegu prowadzonych negocjacji czy charakterystyki ludów barbarzyńskich, nie da się poczynić podobnej refleksji w odniesieniu do kategorii żołnierzy niejednokrotnie znajdującej się w centrum opisywanych wydarzeń. Zaskakujące, że centurionowie nie wzbudzili większego zainteresowania nawet autora podstawowej pracy na temat mechanizmów kreowania przez Cezara wizerunku poszczególnych postaci - Michela Rambauda, który poświęcił osobny wywód legatom i trybunom, choć pod względem barwności ich charakterystyka zdecydowanie ustępuje opisom setników ${ }^{1}$.

${ }^{1}$ M. Rambaud, L’Art de la déformation historique dans les Commentaires de César, Paris 1953, s. 295-301. Zob. późniejsze publikacje poświęcone tym grupom oficerów: J. Suolahti, The Ju- 
Publikacje dotyczące centurionów Cezara przez długi czas miały albo charakter anegdotyczny ${ }^{2}$, albo zawierały streszczenie poszczególnych epizodów z ich udziałem $^{3}$, co w gruncie rzeczy niewiele wnosiło do tematu. Tymczasem kluczowe pozostaje pytanie, do jakiego stopnia wizerunek centurionów stworzony dzięki Commentarii odpowiadał rzeczywistości, a na ile był kreacją literacką obliczoną na uzyskanie konkretnego efektu (a jeśli tak, to jakiego). Rozstrzygnięcie tego problemu wymaga kompleksowej analizy obejmującej nie tylko poszczególne wątki zawarte w Corpus Caesarianum, lecz także informacje pojawiające się w dziełach innych autorów opisujących wydarzenia rozgrywające się w I wieku przed Chr. ${ }^{4}$ W tym kontekście na szczególną uwagę zasługują współczesne publikacje Juana Joségo Palao Vincentego i Davida Nolana traktujące o centurionach pojawiających się w cezariańskiej narracji ${ }^{5}$.

Brak szerszego zainteresowania centurionami unaocznia, że tematyka kampanii prowadzonych przez Cezara tylko pozornie została wyeksploatowana w toku badań filologicznych i historycznych prowadzonych przez kolejne pokolenia uczonych, choć uczciwie należy przyznać, że liczba tematów wymagających jeszcze opracowania nie jest pokaźna. Niemniej pragnąc zrozumieć znaczenie działalności militarnej Cezara dla rozwoju wojskowości rzymskiej oraz charakter pozostawionych przez niego pism, trzeba zmierzyć się z pytaniem, czy tak często chwaleni przez niego centurionowie faktycznie odgrywali znaczącą rolę w działaniach wojennych, czy też ich dokonania zostały sztucznie wykreowane na użytek celów politycznych realizowanych m.in. za pośrednictwem odpowiedniego doboru środków wyrazu literackiego.

nior Officers of the Roman Army in the Republican Period: A Study on Social Structure, Helsinki 1955; J. Harmand, L'armée et le soldat à Rome: de 107 à 50 avant notre ère, Paris 1967, s. 349-383; $\mathrm{K}$. Welch, Caesar and his officers in the Gallic War Commentaries, w: Julius Caesar as Artful Reporter, eds. K. Welch, A. Powell, Swansea 1998, s. 85-110. Do tej pory w najbardziej kompleksowy sposób późnorepublikańskich centurionów scharakteryzował: J. Harmand, L’armée..., s. 324-344.

2 Ch.S. Smith, “Centurio Romanus”: “A First-Class Fightin' Man”, „The Classical Weekly” 1928, 22/3, s. 17-22; R. Cowan, For the Glory of Rome: A History of Warriors and Warfare, London 2007, s. $185-206$.

${ }^{3}$ B. Perrin, The Crastinus Episode at Palaepharsalus, „Transactions of the American Philological Association” 1884, 15, s. 46-57; Th. Horn, Sextius Baculus, „Greece \& Rome” 1961, 8/2, s. 180-183; R. Brown, "Virtus consili expers": An Interpretation of the Centurions' Contest in Caesar, "De bello Gallico” 5, 44, „Hermes” 2004, 132, s. 292-308; R. Cowan, The Real Pullo and Vorenus, „Ancient Warfare" $2007,1 / 2$, s. 25-28.

${ }^{4}$ Wszystkie kolejne daty zamieszczone w tekście odnoszą się do czasów przed narodzeniem Chrystusa, chyba że wyraźnie zaznaczono inaczej.

${ }^{5}$ J.J. Palao Vincente, “Virtus Centurionis”. La figura del centurión en César, „Gerión” 2009, 27/1, s. 191-206; D. Nolan, Caesar's "Exempla" and the Role of Centurions in Battle, w: "Circum Mare": Themes in Ancient Warfare, ed. J. Armstrong, Leiden-Boston 2016, s. 34-62. 


\section{Rola centurionów podczas bitew}

Tworzący w II wieku grecki historyk Polibiusz z Megalopolis scharakteryzował centurionów następująco:

Od centurionów wymagają nie tyle odwagi i zamiłowania do niebezpieczeństw, ile raczej biegłości w dowodzeniu, stałości i przytomności umysłu; i nie tyle, żeby z nienaruszonym oddziałem nacierali i rozpoczynali walkę, lecz żeby wobec przewagi i nacisku nieprzyjaciela wytrwali i umierali w obronie zajmowanej pozycji [przeł. S. Hammer, ze zmianami M.N.F.] ${ }^{6}$.

Z przytoczonego passusu wynika, że nie oczekiwano od centurionów aktów brawury, lecz raczej dbałości o utrzymanie szyku, opanowania i wytrwałości w obliczu naporu przeciwnika. Tymczasem w Commentarii częstokroć mamy do czynienia ze zgoła odmiennym obrazem. Wiarygodność dość ogólnego twierdzenia Polibiusza budzi przy tym pewne wątpliwości, ponieważ w rzymskiej kulturze militarnej indywidualne męstwo (virtus) zawsze było silnie premiowane ${ }^{7}$. Ponadto zwraca uwage utrzymująca się przez cały okres republiki popularność pojedynków toczonych przed frontem wojska ${ }^{8}$, jak również rozbudowany system odznaczeń przyznawanych żołnierzom w dowód uznania ich dzielności, przybierających postać wieńców (coronae), bransolet (armillae) czy „medali” (phalerae) ${ }^{9}$. Nie wydaje się zatem, aby charakterystyka Polibiusza jednoznacznie przeczyła możliwości wykazywania się brawurą na polu bitwy przez przynajmniej niektórych centurionów żyjących przed I wiekiem.

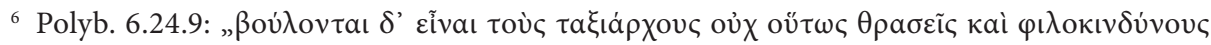

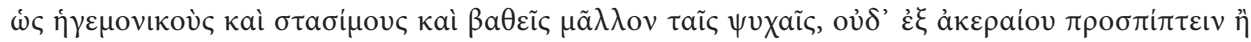

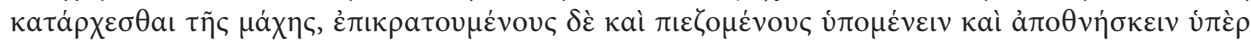

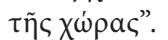

7 W. Eisenhut, „Virtus Romana“: ihre Stellung im römischen Wertsystem, München 1973, s. 40-43; J.E. Lendon, The Rhetoric of Combat: Greek Military Theory and Roman Culture in Julius Caesar's Battle Descriptions, „Classical Antiquity” 1999, 18/2, s. 295-304, 306-322; Idem, Soldiers \& Ghosts: A History of Battle in Classical Antiquity, New Haven-London 2005, s. 172-211; M. McDonnell, Roman Manliness: "Virtus" and the Roman Republic, Cambridge 2006, s. 12-71. Zob. także: W.V. Harris, War and Imperialism in Republican Rome 327-70 BC, Oxford 1979, s. 9-53.

${ }^{\prime}$ S.P. Oakley, Single Combat in the Roman Republic, „The Classical Quarterly” 1985, 35/2, s. 392-410; T. Wiedemann, Singe Combat and being Roman, „Ancient Society” 1996, 27, s. 91-103; A.K. Goldsworthy, The Roman Army at War 100 BC-AD 200, Oxford 1996, s. 264-271; J.E. Lendon, Soldiers \& Ghosts..., s. 172-178; R. Cowan, For the Glory of Rome..., s. 102-183.

${ }^{9} \mathrm{Na}$ temat odznaczeń przyznawanych żołnierzom w republikańskiej armii rzymskiej: V.A. Maxfield, The Military Decorations of the Roman Army, Berkeley_Los Angeles 1981, s. 67-100. 
Niemniej Jon E. Lendon, badając kwestię relacji virtus do disciplina, stwierdził, że w zamyśle dowódców aż do I wieku doświadczeni centurionowie mieli stanowić swoistą przeciwwagę dla młodych, niedoświadczonych trybunów wojskowych, którzy poszukując chwały, zwykli narażać swoje oddziały na zbędne niebezpieczeństwo $^{10}$ - modyfikacja zadań stawianych centurionom byłaby więc ściśle związana $\mathrm{z}$ ewolucją trybunatu.

Problem polega na tym, że podstawowym źródłem wywodów J.E. Lendona (oprócz dzieła Polibiusza) było Ab Urbe condita autorstwa Tytusa Liwiusza, czyli przekaz o specyficznym charakterze, napisany przez człowieka, którego wiedza na temat wojskowości była znacznie ograniczona ${ }^{11}$. Wniosek amerykańskiego badacza odpowiada wprawdzie w ogólnych zarysach zacytowanej obserwacji Polibiusza, ale należy zachować ostrożność w generalizowaniu. Świadczyć o tym może m.in. przykład centuriona nazwiskiem Laevinus, który w 217 roku podczas bitwy stoczonej nad Jeziorem Trazymeńskim miał walczyć nie tylko przy użyciu miecza i tarczy, lecz - po ich utracie - także pięści i zębów ${ }^{12}$. Niewykluczone, że został on stworzony post factum jako exemplum ku chwale rzymskiego oręża, lecz obecność w kulturze plebejskiej takich postaci jak żyjący w V wieku setnik Lucius Siccius Dentatus skłania do podejrzeń, że wzorzec dzielnego żołnierza funkcjonujący przynajmniej w niektórych grupach społeczeństwa rzymskiego niezaliczanych do elity opierał się na indywidualnych dokonaniach ${ }^{13}$. Nawiasem mówiąc, może to stanowić pewien trop w poszukiwaniu odpowiedzi na pytanie, dlaczego Cezar postanowił wyeksponować akurat zasługi centurionów.

Dzieła wchodzące w skład Corpus Caesarianum nie mają sobie równych pod względem szczegółowości opisów warunków codziennego bytowania legionistów, co już samo w sobie czyni je wyjątkowymi. Może to wynikać z regularnego wykorzystywania w konstruowaniu narracji dostarczanych Cezarowi raportów sztabowych, a być może nawet dzienników działań bojowych obfitujących w detale zazwyczaj pomijane w rzymskiej historiografii ${ }^{14}$.

Dotyczy to przede wszystkim losów pojedynczych żołnierzy, których — poza piśmiennictwem Cezara i jego naśladowców - zazwyczaj pomijano. Przykładowo, w bitwie stoczonej w 48 roku pod Farsalos uczestniczył dawny primus pilus ${ }^{15}$

\footnotetext{
${ }^{10}$ J.E. Lendon, Soldiers \& Ghosts..., s. 229-230.

11 Zob. P.G. Walsh, Livy: His Historical Aims and Methods, Cambridge 1961, s. 4, 157-163; T.J. Luce, Livy: The Composition of His History, Princeton 1977, s. 224-226, 267-268; D.S. Levene, Livy on the Hannibalic War, Oxford 2010, s. 16-33.

12 Sil. Ital., Pun. 6.43-57.

13 Dion. Hal. 10.37.3; Val. Max. 3.2.24; Plin., NH 7.101; Gell. 2.11.3; Fest. 208 L.

14 M. Rambaud, L'Art de la déformation..., s. 61-66, 77-96; J. Harmand, L'armée..., s. 142, $145,148$.

15 Na temat gradacji rang w obrębie stopnia centuriona: Th. Wegeleben, Die Rangordnung die römischen Centurionen, Berlin 1913, s. 23-50; M. Radin, The Promotion of Centurions in
} 
X legionu - Caius Crastinus ${ }^{16}$. Według Cezara wsławił się on następującym czynem:

W wojsku Cezara znajdował się evocatus C. Crastinus, który w ubiegłym roku pełnił funkcję primusa pilusa X legionu, mąż o wyjątkowej dzielności. [...] Następnie zwrócił się do Cezara ze słowami: „Wodzu, dziś tak się sprawię, że podziękujesz mi bądź żywemu, bądź martwemu”. Gdy to powiedział, pierwszy wybiegł z prawego skrzydła do przodu, a za nim ruszyło około 120 doborowych ochotników należących do tej samej centurii [przeł. E. Konik, ze zmianami M.N.F. $]^{17}$.

Takie zachowanie stoi w sprzeczności z opinią wyrażoną przez Polibiusza, co może sugerować, że w czasie dzielącym powstanie obu dzieł doszło do ewolucji zadań stawianych centurionom. Przykład Crastinusa nie jest bowiem odosobniony - w 45 roku, zanim doszło do starcia w rejonie Ukubis, dwóch centurionów należących do armii Cezara i Gnejusza Pompejusza Młodszego: Quintus Pompeius Niger i Antistius Turpio, postanowiło natchnąć swoich towarzyszy do walki poprzez stoczenie pojedynku przed frontem wojsk ${ }^{18}$. W 52 roku podczas oblężenia Gergowii atakowi na galijskie obwarowania przewodzili dwaj centurionowie VIII legionu: Lucius Fabius i Marcus Petronius ${ }^{19}$. Obaj przypłacili brawurę życiem. Łącznie tego dnia miało paść na placu boju aż 46 centurionów, co jednoznacznie dowodzi, że to właśnie oni wzięli na siebie główny ciężar szturmu ${ }^{20}$. Dla kontrastu warto wspomnieć, że w 46 roku, tuż przed bitwą stoczoną pod Tapsus centurionowie własnym ciałem zagradzali drogę żołnierzom, którzy rwali się do walki mimo braku stosownego rozkazu ${ }^{21}$, co należy odczytać jako próbę zapobieżenia chaotycznemu rozwojowi wypadków. Abstrahując od niemożliwego do ustalenia stopnia stylizacji opisów przywołanych wydarzeń, można odnieść wrażenie, że przedstawiona przez

Caesar's Army, „The Classical Journal” 1915, 10/7, s. 300-311; H.M.D. Parker, A Note on the Promotion of the Centurions, „The Journal of Roman Studies” 1926, 16, s. 45-52; Idem, The Roman Legions, $2^{\text {nd }}$ edition, New York 1958, s. 31-35; J. Harmand, L'armée..., s. 327-333.

${ }_{16}$ Inna wersja jego nazwiska to Crassinius (Plut., Caes. 44.9-12).

${ }^{17}$ Caes., Bell. civ. 3.91.1-3: „Erat C. Crastinus evocatus in exercitu Caesaris, qui superiore anno apud eum primum pilum in legione $\mathrm{X}$ duxerat, vir singulari virtute. [...] Simul respiciens Caesarem, »faciam, « inquit, »hodie, imperator, ut aut vivo mihi aut mortuo gratias agas.» Haec cum dixisset, primus ex dextro cornu procucurrit, atque eum electi milites circiter CXX voluntarii eiusdem cohortis sunt prosecuti". O udziale Crastinusa w bitwie pod Farsalos zob. także: Caes., Bell. civ. 3.99.3-4; Luc., Phar. 7.471-472; Plut., Pomp. 71.3; App., Bell. civ. 2.82.347-348; Flor. 2.13.46. Zob. podobny epizod, który rozegrał się ponad 100 lat później podczas oblężenia Jerozolimy: Joseph., BJ 6.54-67.

${ }^{18}$ Bell. Hisp. 25.3-7.

${ }^{19}$ Caes., Bell. Gall. 7.47.5-7, 7.50.3-6.

${ }^{20}$ Caes., Bell. Gall. 7.51.1-2.

${ }^{21}$ Bell. Afr. 82.4 . 
Polibiusza wizja republikańskiego centurionatu została poszerzona o inicjatywę bitewną, przynajmniej w obrębie armii Cezara.

W 57 roku pod Oktodurus impuls do ataku wyszedł m.in. od primusa pilusa XII legionu Publiusa Sextiusa Baculusa, który wraz z trybunem Caiusem Volusenusem Quadratusem uznał, że lepiej podjąć próbę przebicia się przez linie wroga, niż czekać w obozie na pewną śmierć ${ }^{22}$. Znacznie mniej racjonalnym przykładem brawury, acz opisanym przez Cezara z nieukrywanym uznaniem, była z kolei rywalizacja centurionów Titusa Pullona i Luciusa Vorenusa, którzy w 54 roku próbowali prześcignąć się w liczbie zabitych nieprzyjaciół. W tym celu zwykli wyłamywać się z szeregów, porzucając de facto oddziały, którymi winni byli dowodzićn ${ }^{23}$. Podobną odwagą, a jednocześnie większym poczuciem odpowiedzialności wykazało się w 45 roku dwóch anonimowych centurionów służących w $\mathrm{V}$ legionie:

Kiedy więc zauważono w obozie, że nasi wbrew zwyczajowi wycofują się, wtedy dwaj centurionowie z V legionu, przekroczywszy rzekę, ustawili naszych z powrotem w szyku bojowym. Gdy z nadzwyczajnym męstwem obaj zażarcie odpierali licznych wrogów, jeden z nich padł pod gradem pocisków miotanych z wyżej położonych stanowisk. Kiedy jego współtowarzysz spostrzegł w wirze walki, że jest ze wszystkich stron okrążany, ruszył do ataku i uszkodził sobie nogę. Tłum przeciwników natychmiast rzucił się na oznaki godności tego upadającego centuriona i dzielnego żołnierza [...] [przeł. E. Konik] ${ }^{24}$.

Gdy w 57 roku nad Sabis Cezar wydał rozkaz przeprowadzenia kontrataku, odwołał się imiennie właśnie do centurionów, którzy mieli porwać za sobą żołnie$\mathrm{rzy}^{25}$. W 53 roku centurionowie dwukrotnie nacierali na przeciwnika, aby osłonić odwrót ulegających panice legionistów ${ }^{26}$. Wszystko to pokazuje, że z jednej strony wymagano od setników przewodzenia żołnierzom podczas walki i inspirowania ich przykładami własnego męstwa, lecz z drugiej — oczekiwano przynajmniej elementarnego poczucia odpowiedzialności za powierzone im centurie, zgodnie z tym, co pisał na ten temat Polibiusz. Jedyny w tym zestawieniu przykład braku wyobraźni

${ }^{22}$ Caes., Bell. Gall. 3.5.2-3.

${ }^{23}$ Caes., Bell. Gall. 5.44.1-14.

${ }^{24}$ Bell. Hisp. 23.3-5: „Itaque praeter consuetudinem cum a nostris animadversum esset cedere, centuriones ex legione $\mathrm{v}$ flumen transgressi duo restituerunt aciem, acriterque eximia virtute plures cum agerent, ex superiore loco multitudine telorum alter eorum concidit. Ita cum eius compar proelium facere coepisset, cum undique se circumveniri animum advertisset, in[teger re]gressus pedem offendit. Huius concidentis temporis aquari fortis insignia cum conplures adversariorum concursum facerent [...]".

${ }^{25}$ Caes., Bell. Gall. 2.25.2-3.

${ }^{26}$ Caes., Bell. Gall. 6.38.3-5, 6.40.7-8. 
okazany przez Pullona i Vorenusa nie zmienia w znaczący sposób tej konstatacji, sugeruje jedynie, że pogoń za osobistą chwałą i wyróżnieniami okazywała się niekiedy ważniejsza od realizacji zadań taktycznych. Obaj pragnęli bowiem usilnie uzyskać awans na wyższe stanowisko w obrębie stopnia centuriona ${ }^{27}$.

Jedna kwestia nie zmieniła się na przestrzeni czasów, mianowicie centurionowie podczas bitwy w dalszym ciągu byli odpowiedzialni za utrzymanie powierzonych im pozycji. Wspomniany epizod z 45 roku odbywający się z udziałem dwóch anonimowych centurionów pośrednio potwierdza taką obserwację ${ }^{28}$. Bezpośrednio dowodzi tego natomiast powód, dla którego Cassius Scaeva został w 48 roku wyróżniony przez Cezara:

Obrońcy tej strażnicy chcieli dostarczyć Cezarowi dowody swoich trudów i niebezpieczeństw, więc obliczyli, że na strażnicę wypuszczono około 30000 strzał, a na przyniesionej tarczy centuriona Scaevy znaleziono 120 dziur. Cezar nagrodził go za zasługi wobec siebie i republiki sumą 200000 sesterców, udzielając mu pochwały w obecności całego wojska, i ogłosił, że awansuje go z centuriona ósmej rangi na primipilusa (wiadomo bowiem było, że to głównie dzięki jego bohaterstwu strażnica ocalała) [przeł. E. Konik, ze zmianami M.N.F.] $]^{29}$.

W 37 roku podczas kampanii prowadzonej na Półwyspie Iberyjskim przeciwko Cerretanom za porzucenie pozycji zdziesiątkowano dwie centurie legionistów. $\mathrm{Na}$ śmierć skazano także centuriona w randze primusa pilusa, który zhańbił się ucieczką w obliczu natarcia wroga ${ }^{30}$. W świetle przytoczonych przykładów jest to kolejne po-

${ }^{27}$ Caes., Bell. Gall. 5.44.1-2. Mimo jednoznacznego w wymowie przekazu Cezara niektórzy badacze przypuszczają, że cała scena miała na celu podniesienie ducha bojowego oblężonych rzymskich oddziałów. Tak np. A.K. Goldsworthy, The Roman Army..., s. 269-270, 279; R. Brown, "Virtus consili expers"..., s. 292-308. Jeśli tak było w istocie, to Pullo i Vorenus starali się uzyskać ów efekt przy okazji starań o awans, natomiast jest mało prawdopodobne, aby był ich głównym celem. Co ciekawe, obie postaci stały się bohaterami popkultury z uwagi na ukazanie ich w wyprodukowanym przez HBO serialu Rzym (2005-2007). Objawem rosnącego zainteresowania Pullonem i Vorenusem stał się nie tylko popularnonaukowy artykuł, w treści którego zaprezentowano ich prawdziwą historię (R. Cowan, The Real Pullo..., s. 25-28), lecz także naukowa analiza niektórych wątków zawartych w serialu (L.L. Brice, Discharging Pullo and Vorenus: Veterans in Rome, w: Rome, Season Two: Trial and Triumph, ed. M.S. Cyrino, Edinburgh 2015, s. 25-35).

${ }^{28}$ Bell. Hisp. 23.1-5.

${ }^{29}$ Caes., Bell. civ. 3.53.4-5: „Et cum laboris sui periculique testimonium afferre vellent, milia sagittarum circiter XXX in castellum coniecta Caesari renumeraverunt, scutoque ad eum relato Scaevae centurionis inventa sunt in eo foramina CXX. Quem Caesar, ut erat de se meritus et de re publica, donatum milibus CC collaudatumque ab octavis ordinibus ad primipilum se traducere pronuntiavit (eius enim opera castellum magna ex parte conservatum esse constabat)".

${ }^{30}$ Cass. Dio 48.42.2. Por. anegdotę zawartą w: Cic., De or. 2.67, gdzie jest mowa o ukaraniu centuriona degradacją z powodu uchylenia się przez niego od walki. Jej prawdziwość nie ma w tym 
twierdzenie przypuszczenia, że do zadań centurionów należało m.in. zapobieganie przerywaniu szyków oraz utrzymywanie wyznaczonych pozycji. W ich realizacji mieli im pomagać optiones znajdujący się tuż za szeregami walczących i dzierżący zakończone gałkami kije, za pomocą których powstrzymywali od ucieczki żołnierzy ustawionych w tylnych szeregach, po prostu wymierzając im w razie potrzeby ciosy ${ }^{31}$.

Wszystkie przywołane wzmianki na temat odwagi wykazywanej przez centurionów odnoszą się do armii Cezara. Kluczowe staje się zatem pytanie, czy podobne opisy zachowały się także w dziełach innych autorów i czy przywiązywanie tak dużego znaczenia do indywidualnych osiągnięć nie było specyficzną cechą tego wodza. Dla poznania podejścia Cezara znamienny wydaje się passus odnoszący się do decydującej bitwy stoczonej w 58 roku z armią Ariowista: „Na czele poszczególnych legionów Cezar postawił legatów i kwestora, aby każdy żołnierz miał w nich świadków swego męstwa [przeł. E. Konik]" ${ }^{32}$. Prawdopodobnie nie chodziło w tym przypadku o wyrażenie symbolicznego uznania przez zwierzchników, lecz o późniejsze nagrodzenie zaobserwowanego bohaterstwa. Szczególnie zasłużonych żołnierzy Cezar zwykł publicznie wyróżniać przed frontem wojska. Stało się tak zarówno w przypadku Scaevy ${ }^{33}$, jak i oddziału sprzymierzeńczej konnicy, której w 45 roku udało się wyprzeć pompejańczyków z pola bitwy ${ }^{34}$. Cezar miał także zwyczaj wymieniania na kartach Commentarii nazwisk centurionów, którzy dzielnie stawiając czoła wrogowi, odnieśli rany bądź zostali zabici ${ }^{35}$.

Charakter zachowanych źródeł dotyczących schyłku republiki nie ułatwia poszukiwania opisów odwagi centurionów, które byłyby podobne do cezariańskich. Wynika to przede wszystkim z faktu, że jedynie Cezar zwykł regularnie pisać o do-

przypadku większego znaczenia - o wiele istotniejsze są cechy, którymi w powszechnym wyobrażeniu miał się wykazywać centurion.

${ }^{31}$ M.P. Speidel, The framework of an Imperial legion. The fifth annual Caerleon lecture in honorem Aquilae Legionis II Augustae, Cardiff 1992, s. 24-26; A.K. Goldsworthy, The Roman Army..., s. 182. Na kluczowe znaczenie utrzymania spójności ostatnich szeregów podczas prowadzenia walki uczulał niegdyś: [Ch.] Ardant du Picq, Études sur le combat, Paris 1880, s. 67. W takich sytuacjach istotne jest wyselekcjonowanie oficerów niższego stopnia/podoficerów/żołnierzy funkcyjnych, którzy mogliby zapobiec rozprzestrzenianiu się paniki i utrzymaliby zajmowaną pozycję oddziałów. Zob. S. Konieczny, Strach i odwaga w działaniach bojowych, Warszawa 1964, s. 89-90, 94-95. Zob. S.L.A. Marshall, Men against Fire: The Problem of Battle Command, $2^{\text {nd }}$ edition, Norman 2000 , s. 62 .

${ }^{32}$ Caes., Bell. Gall. 1.52.1: „Caesar singulis legionibus singulos legatos et quaestorem praefecit, uti eos testes suae quisque virtutis haberet".

${ }^{33}$ Caes., Bell. civ. 3.53.4-5.

${ }^{34}$ Bell. Hisp. 26.1-2. Na temat pozytywnego wpływu takich uroczystości na morale żołnierzy, również tych, którzy nie zostali nagrodzeni, zob.: S. Konieczny, Strach i odwaga..., s. 213-214; R. Holmes, Acts of War: the Behaviour of Men in Battle, $2^{\text {nd }}$ edition, London 2003, s. 300-302.

${ }_{35}$ Przykładowo: Caes., Bell. Gall. 5.35.6-8, 6.38.1-5, 7.50.4-6; Bell. civ. 1.46.3-4. 
konaniach prostych żołnierzy służących pod jego rozkazami ${ }^{36}$ - pozostali autorzy skupiali się niemal wyłącznie na czynach czołowych postaci żyjących w I wieku. W pryncypacie takie postrzeganie centurionów było już natomiast dobrze ugruntowane. Kasjusz Dion wspomniał o Luciusie Tettiusie Julianusie, który tuż przed bitwą pod Tappae stoczoną w 88 roku po Chr. nakazał żołnierzom wypisać na tarczach m.in. nazwiska dowodzących nimi centurionów, aby móc lepiej dostrzec, kto wyróżnił się podczas walki, a kto okazał się tchórzem ${ }^{37}$. Stanowi to dla współczesnego historyka jasny sygnał, że odwaga była przez rzymskich wodzów odpowiednio nagradzana bez względu na analizowany okres.

Bohaterskich centurionów VII legionu, którzy polegli w 69 roku po Chr., opisał Publiusz (?) Korneliusz Tacyt. Był wśród nich Atilius Varus, któremu z największym trudem udało się ocalić orła swojej jednostki ${ }^{38}$. Indywidualne popisy w iście cezariańskim stylu stały się natomiast udziałem centuriona Julianusa, który w 70 roku po Chr. samodzielnie odpierał ataki przeważającego liczebnie przeciwnika ${ }^{39}$. Zachowane nagrobki centurionów pochodzące z I-II wieku po Chr. zawierają liczne przedstawienia nagród przyznawanych za dzielność, jak np. w przypadku płaskorzeźb nagrobnych Marcusa Caeliusa, Quintusa Sertoriusa Festusa, Caiusa Alliusa Oriensa, Marcusa Petroniusa Classicusa czy Caiusa Gaviusa Celera. Zestawienie sporządzone przez Valerie A. Maxfield obejmuje ponad 40 znanych współcześnie nazwisk takich centurionów ${ }^{40}$. Dość powiedzieć, że tylko w przypadku nielicznych przedstawicieli tej kategorii cesarskich żołnierzy nie mamy do czynienia z wyobrażeniami dona militaria, co nie jest, rzecz jasna, równoznaczne z ich brakiem. Na tej podstawie udało się nawet opracować ogólny system przyznawania odznaczeń dla centurionów. Wynika z niego, że bez znaczących dokonań bojowych objęcie tego stanowiska było utrudnione, jeśli w ogóle możliwe ${ }^{41}$.

Niewątpliwie zasada ta stanowiła dziedzictwo późnej republiki, niekoniecznie jednak należy łączyć ją z Cezarem. Już wcześniej centurionowie musieli być traktowani jako elita legionów, w przeciwnym razie nie powierzano by im zadań o specjalnym znaczeniu. W 107 albo w 106 roku Gajusz Mariusz rozkazał centurionom i wybranym żołnierzom zająć wzniesienie położone nieopodal rzeki Muluchy, czego dokonali mimo obecności stawiającego opór przeciwnika ${ }^{42}$. W 62 roku pod Pistorią Lucjusz Sergiusz Katylina podjął decyzję o przesunięciu zmobilizowanych

\footnotetext{
${ }^{36}$ Rzecz jasna, mowa jest o zachowanych źródłach, nie wiadomo bowiem, w jaki sposób narrację budowali Lucius Cornelius Sisenna czy Caius Asinius Pollio, gdyż zachowane fragmenty ich prac nie pozwalają na przedstawienie szerszych wniosków na ten temat.

${ }^{37}$ Cass. Dio 67.10.1-2.

38 Tac., Hist. 3.22.

39 Joseph., BJ 6.81-92.

40 V.A. Maxfield, The Military Decorations..., s. 186-187.

41 Ibidem, s. 184-200.

${ }^{42}$ Frontin., Str. 3.9.3. Por. Sall., Jug. 93.8.
} 
centurionów weteranów do pierwszej linii, upatrując w nich najbardziej wartościowy element armii ${ }^{43}$. Nic dziwnego zatem, że w 49 roku Cezar powierzył zajęcie Ariminium oddziałowi złożonemu głównie z centurionów ${ }^{44}$.

W 67 roku, gdy doszło do klęski wojsk Caiusa Valeriusa Triariusa w walce z armią Mitrydatesa VI Eupatora, nieznany z nazwiska centurion ku zaskoczeniu wszystkich rzucił się na króla Pontu i ciężko go ranił, czym znacząco opóźnił pościg za uchodzącymi towarzyszami broni ${ }^{45}$. Swoim poświęceniem potwierdził gotowość sprostania obowiązkom stawianym centurionom. W 44 roku Marek Antoniusz utworzył z nich gwardię przyboczną w sile legionu (6000 ludzi), co wywołało poważne zaniepokojenie wśród jego oponentów politycznych zasiadających w sena$\mathrm{cie}^{46}$. Można domniemywać, że nie uczyniłby tego, gdyby nie uważał centurionów za legionową elitę. Służący w latach 40. i 30. I wieku pod rozkazami późniejszego cesarza Augusta centurion Lucius Blattius Vetus z legio IIII (IV) Macedonica nakazał przedstawić na swoim nagrobku liczne dona militaria (9 phalerae i 2 armillae), które otrzymał w uznaniu dzielności ${ }^{47}$.

Tego rodzaju przykłady sugerują, że Cezar nie był autorem innowacji odnoszącej się do formy sprawowania centurionatu, co najwyżej odegrał rolę katalizatora pewnych procesów, które za pośrednictwem jego dziedziców politycznych (przede wszystkim Antoniusza i Augusta) znalazły kontynuację w okresie cesarstwa.

Potwierdzeniem znaczenia centurionów w bitwach były wysokie straty, jakie ponosili, wynikające $\mathrm{z}$ wyznaczania im pozycji w pierwszym szeregu centurii ${ }^{48}$. Współcześnie nie mamy pewności, czy zwykli zajmować miejsce pośrodku formacji bojowej, czy też na jej skraju, ale w kontekście liczby ofiar nie ma to większego znaczenia. Jacques Harmand stwierdził nawet, że jednym z podstawowych zadań

${ }^{43}$ Sall., Cat. 59.3.

${ }^{44}$ App., Bell. civ. 2.35.137.

45 App., Mihr. 89.404.

${ }^{46}$ App., Bell. civ. 3.5.14.

${ }^{47}$ Na temat przebiegu kariery Blattiusa Vetusa i datacji wspomnianego nagrobka zob.: L. Keppie, Colonisation and Veteran Settlement in Italy, 47-14 BC, Rome 1983, s. 214; C. Franzoni, "Habitvs atqve habitvdo militis". Monumenti funerari di militari nella Cisalpina Romana, Roma 1987, s. 49-50; R. D'Amato, Roman Centurions 31 BC-AD 500: The Classical and Late Empire, Oxford 2012, s. 6, 44; M.N. Faszcza, Wyobrażenia późnorepublikańskich centurionów i ich znaczenie dla badań nad wojskowościa rzymska w I w. przed Chr., „Res Historica” 2015, 40, s. 23-26.

${ }^{4}$ A.D. Lee, Morale and the Roman Experience of Battle, w: Battle in Antiquity, ed. A.B. Lloyd, Swansea 1996, s. 201, 211; A.K. Goldsworthy, The Roman Army..., s. 182; P. Sabin, The Face of Roman Battle, „The Journal of Roman Studies” 2000, 90, s. 11; J.E. Lendon, Soldiers \& Ghosts..., s. 302; K. Resch, „Omnibus centurionibus occisis“ - Überlegungen zu relativen Verlustzahlen bei Caesar, „Historia” 2010, 59/1, s. 122-127. Na temat strat ponoszonych przez centurionów służących w armii Cezara: Bell. Gall. 2.25.1, 7.50.3-6, 7.51.1-2; Bell. civ. 1.46.3-4, 3.99.1; Bell. Alex. 43.1-3. Por. Tac., Ann. 12.38; Hist. 3.22. Z pewnością znacznym problemem dla badaczy wojskowości rzymskiej okresu cesarstwa jest brak równie szczegółowych informacji. 
centurionów było czynienie wyłomów w szykach przeciwnika, na podobieństwo tarana ${ }^{49}$. Prawdopodobnie wyjaśnia to przy okazji, dlaczego właśnie centurionowie zostali przedstawieni w dziełach Cezara i jego kontynuatorów jako postaci cechujące się wyjątkową walecznością - predestynowało ich do tego już samo umiejscowienie w szyku bojowym ${ }^{50}$. Każe to spojrzeć na opisy zawarte w Corpus Caesarianum z dużą dozą zaufania, bo choć przebieg poszczególnych epizodów mógł się różnić szczegółami od późniejszych opisów, to już samo uwzględnienie realnie stosowanych rozwiązań taktycznych do pewnego stopnia je uwiarygodnia.

Wzrost znaczenia centurionów podczas bitew wynikał najprawdopodobniej z ugruntowania na przełomie II i I wieku kohort, co w efekcie doprowadziło do zwiększenia roli centurii kosztem manipułów. Choć te ostatnie nie zniknęły z armii rzymskiej i sam Cezar wielokrotnie o nich wspominał, to nie ulega wątpliwości, że doszło do ich stopniowej marginalizacji, gdyż w przypadku realizacji taktyki kohortalnej kluczowego znaczenia nabierało współdziałanie większych, a jednocześnie elastyczniejszych oddziałów - w tym przypadku kohort ${ }^{51}$.

W odniesieniu do I wieku coraz rzadszym zjawiskiem stało się opisywanie dokonań trybunów wojkkowych, co jest łączone nie tylko z pojawieniem się nowej kategorii oficerów wyższego stopnia (legatów), często legitymizujących się wieloletnim doświadczeniem militarnym, lecz także z postępującym od III wieku wzrostem liczebności legionów prowadzącym do zdewaluowania stopnia trybuna ${ }^{52}$. Należy podkreślić, że jest to współczesna konstrukcja historiograficzna, która - choć nosi wysokie znamiona prawdopodobieństwa — nie znajduje bezpośredniego potwier-

49 J. Harmand, L'armée..., s. 338-340.

50 Mogłoby się wydawać, że takie usytuowanie zwierzchników mających kluczowe znaczenie dla przebiegu bitew jest nieracjonalne, jednakże z punktu widzenia psychologii wojskowej istotne jest, aby osoba sprawująca bezpośrednie dowództwo przewodziła nacierającym, a nie znajdowała się za nimi. Co więcej, ciąży na niej obowiązek podtrzymywania ataku, a jej przykład ma kluczowe znaczenie dla postawy podwładnych. Siłą rzeczy wiąże się to z poważnym ryzykiem utraty przez nią życia. Problem ten był opisywany m.in. przez: [Ch.] Ardant du Picq, Études sur le combat..., s. 110-111; Lord Moran, The Anatomy of Courage, $2^{\text {nd }}$ edition, London 1966, s. 98; J. Keegan, The Face of Battle, New York 1976, s. 188; S.L.A. Marshall, Men against Fire..., s. 115; R. Holmes, Acts of War..., s. 341-342; D. Grossman, O zabijaniu. Psychologiczny koszt kształtowania gotowości do zabijania w czasach wojny i pokoju, przeł. D. Konowrocka, Warszawa 2010, s. 126; L. Murray, Psychologia wojny. Strach i odwaga na polu bitwy, przeł. E. Zajbt, Warszawa 2014, s. 114-115.

${ }^{51}$ Zob. G. Veith, Die Taktik der Kohortenlegion, „Klio” 1907, 7, s. 303-334; Th. Steinwender, Zur Kohortentaktik, „Rheinisches Museum für Philologie” 1915, 70, s. 416-440; H. Delbrück, Geschichte der Kriegskunst im Rahmen der politischen Geschichte, I, Das Altertum, 3. Auflage, Berlin 1920, s. 496-498; M.J.V. Bell, Tactical Reform of the Roman Republican Army, „Historia” 1965, 14/4, s. 404-422; A.K. Goldsworthy, The Roman Army..., s. 171-183; M.J. Taylor, Tactical Reform in the Late Roman Republic: The View from Italy, „Historia” 2019, 68/1, s. 76-94.

52 H.M.D. Parker, The Roman Legions..., s. 18; L. Keppie, The Making of the Roman Army: From Republic to Empire, London 1984, s. 177; W.V. Harris, War and Imperialism..., s. 13. Zob. H. Delbrück, Geschichte der Kriegskunst..., s. 516-517. 
dzenia w treści źródeł. Clarence E. Brand uczulał nawet, aby nie traktować jej jako pewnika, ponieważ zachowane przekazy nie zawierają opisów rażącej niekompetencji trybunów ${ }^{53}$. Nie jest to argument przekonujący, jako że niewielkie zainteresowanie dziejopisarzy trybunami mogło wynikać właśnie z obniżenia ich rangi, ściśle związanego z przeniesieniem części kompetencji na legatów i centurionów. Faktem natomiast pozostaje, że widoczny w I wieku wzrost znaczenia centurionów zbiegł się w czasie z odwrotnym procesem, którego ofiarą padli trybuni.

\section{Warunki pełnienia służby}

Jeśli domniemanie o dużym znaczeniu centurionów w armii rzymskiej I wieku miałoby się potwierdzić, to konieczne staje się prześledzenie zmian, jakie zaszły w zakresie warunków pełnionej przez nich służby. Nie chcąc powtarzać wywodów zawartych we wcześniejszych publikacjach poświęconych tej kategorii żołnierzy ${ }^{54}$, ograniczę się do zestawienia najważniejszych faktów.

Wysokość poborów centurionów i przyznawanych im nagród tradycyjnie była dwa razy większa niż korzyści finansowe odnoszone przez zwykłych legionistów $^{55}$. Już w latach poprzedzających podbój Galii przez Cezara (58-51) można było jednak dostrzec jej nawet dwudziestokrotny wzrost ${ }^{56}$. Jednoznacznie wskazuje to na zwiększenie znaczenia centurionów na początku I wieku, a także dowodzi, że to nie Cezar był autorem dokonujących się zmian. Ponadto znane są przypadki włączania centurionów w poczet senatorów ${ }^{57}$, a nagrobki Minuciusa Lorariusa czy wspomnianego już Blattiusa Vetusa dowodzą, że po zakończeniu służby mieli oni duże szanse na wejście w skład elit municypalnych ${ }^{58}$. Dla żoł-

53 C.E. Brand, Roman Military Law, Austin Brand 1968, s. 51, przyp. 19.

${ }^{54}$ M.N. Faszcza: „Vitis centurionis”, czyli o okolicznościach nadania centurionom symbolu ich rangi, „Przegląd Historyczno-Wojskowy” 2015, 2, s. 7-20; Idem, Wzrost dyscyplinarnych uprawnień centurionów w I w. p.n.e., w: Armia, systemy obronne i ideologiczno-religijne aspekty wojny w imperium rzymskim, red. H. Kowalski, P. Madejski, Lublin 2015, s. 11-25.

55 Polyb. 6.39.12-13; Liv. 33.23.7, 34.46.2, 34.52.4, 36.40.12, 37.59.3, 39.5.14, 39.7.1, 40.34.2, 40.43.5, 40.59.2, 41.7.1, 41.13.6, 45.40.5, 45.43.4. Wyjątkiem była sytuacja ze 196 roku: Liv. 33.37.11.

${ }^{56}$ Caes., Bell. Gall. 4.8.1; Hirt., Bell. Gall. 8.4.1; Plut., Pomp. 33.5; App., Mithr. 104.490.

${ }^{57}$ Cic., Att. 9.10.7, 9.18.2, 14.10.2; Tac., Hist. 1.55.2; Ann. 3.75.1; Suet., Jul. 76.3, 80.2; Cass. Dio 48.22.3; Oros. 5.21.3. Por. Sall., Cat. 37.6. Wspomniane zjawisko opisali: R. Syme, The Roman Revolution, Oxford 1939, s. 78-79; M. Gelzer, The Roman Nobility, trans. R. Seager, New York 1969, s. 5, 14; E. Gabba, Republican Rome, the Army \& the Allies, trans. P.J. Cuff, Oxford 1976, s. 34, 48, 51-52, 144.

58 C. Franzoni, Il monumento funerario patavino di un militare e un aspetto dei rapporti artistici tra zone provinciali, „Rivista di Archeologia” 1982, 6, s. 47-51; Idem, "Habitvs atqve habitvdo mi- 
nierzy pokroju Lorariusa, który w momencie wstąpienia do legionu najprawdopodobniej nie miał nawet obywatelstwa rzymskiego, podniesienie do kategorii ekwitów było znaczącym awansem społecznym. Wysoki status materialny centurionów znalazł odbicie w opisie usunięcia niektórych z nich z szeregów $\mathrm{X}$ legionu:

[...] zwołał [Cezar - M.N.F.] następnego dnia wszystkich trybunów wojskowych oraz centurionów i tak do nich z trybunału przemówił: „Bardzo życzyłbym sobie, ażeby ludzie raz wreszcie położyli kres swojej bezczelności i wybujałemu rozpasaniu i mieli wzgląd na moją pobłażliwość, łagodność i cierpliwość! Ale ponieważ nie potrafili sami sobie wyznaczyć ani miary, ani granicy, to ja sam postanawiam, zgodnie $\mathrm{z}$ regulaminem wojskowym, dać taki oto przykład, aby inni odpowiednio się prowadzili” [przeł. E. Konik] ${ }^{59}$.

W dalszej części Cezar wymienił imiennie tylko trybunów wojkkowych winnych naruszenia dyscypliny z powodu ostentacyjnej dbałości o majątek, ale skierowanie przemowy także do centurionów sugeruje, że w ich szeregach również mogło dochodzić do tego typu nadużyć60.

U schyłku republiki centurionowie otrzymali prawo do wymierzania chłosty, co było prawdopodobnie związane z próbami obejścia ograniczeń, które w kwestiach dyscyplinarnych nakładały na wodzów leges Porciae $(199-193)^{61}$. Przyczyniło się to do powstania widocznego w okresie cesarstwa podziału na kary i środki dyscyplinarne - zastosowanie tych drugich nie wymagało udziału dowódcy, ponieważ ich orzeczenie leżało głównie w gestii centurionów ${ }^{62}$. Włączenie setników do systemu zachowywania karności było innowacją o znaczeniu trudnym do przecenienia, i to nie tylko wziąwszy pod uwagę tradycyjne mechanizmy utrzymywania posłuszeństwa w legionach, lecz przede wszystkim znaczne wywyższenie centurionów w hierarchii dowódczej.

litis”..., s. 46-48; L. Keppie, A centurion of “legio Martia” at Padua?, „Journal of Roman Military Equipment Studies" 1991, 2, s. 115-121; R. D'Amato, Roman Centurions 753-31 BC: The Kingdom and the Age of Consuls, Oxford 2011, s. 21-24, 33, 47; M.N. Faszcza, Wyobrażenia późnorepublikańskich centurionów..., s. 15-26.

${ }^{59}$ Bell. Afr. 54.1-4: „[...] postero die de suggestu convocatis omnium legionum tribunis centurionibusque 'Maxime vellem' inquit 'homines suae petulantiae nimiaeque libertatis aliquando finem fecissent meaeque lenitatis modestiae patientiaeque rationem habuissent. Sed quoniam ipsi sibi neque modum neque terminum constituunt, quo ceteri dissimiliter se gerant, egomet ipse documentum more militari constituam".

${ }^{60}$ Bell. Afr. 54.4-6.

${ }^{61}$ M.N. Faszcza, „Vitis centurionis”..., s. 7-20; Idem, Wzrost dyscyplinarnych uprawnień..., s. $11-25$.

${ }^{62}$ M.N. Faszcza, „Vitis centurionis”..., s. 15-16. 
Primus pilus (primipilus) każdego legionu uczestniczył w odprawach rady wojennej (consilium) ${ }^{63}$, choć nie jest jasne, jaka była jego rola. Można domniemywać, że jako faktyczny dowódca legionu, a jednocześnie jedyny w pełni zawodowy żołnierz biorący udział w odprawie cieszył się należnym szacunkiem zarówno ze strony zwierzchników, jak i podwładnych. Interesujące informacje na temat centurionów uczestniczących w consilium zawiera passus pochodzący z Commentarii de bello Gallico odnoszący się do rozbicia oddziałów Quintusa Tituriusa Sabinusa i Luciusa Aurunculeiusa Cotty w 54 roku:

Legaci przekazali sprawę radzie wojennej, na której doszło do gwałtownej wymiany zdań między jej uczestnikami. Lucius Aurunculeius, wielu trybunów i centurionów pierwszej rangi było zdania, że niczego nie należy pochopnie czynić ani też porzucać kwater zimowych bez rozkazu Cezara; [...]. Gdy po wypowiedziach obydwu stron Cotta i centurionowie pierwszej rangi uparcie obstawiali przy swoim, Sabinus począł krzyczeć, i to tak głośno, aby wielka część żołnierzy mogła go usłyszeć: [...]. Uczestnicy narady zrywają się z miejsc; chwytają ich za ręce i proszą, aby przez swój brak zgody i upór nie doprowadzili wszystkiego do ostatecznego zagrożenia: [...]. Wreszcie Cotta, choć nie przekonany, ustąpił [przeł. E. Konik, ze zmianami M.N.F. $]^{64}$.

Pomijając silny efekt retoryczny opisu, należy zwrócić uwagę nie tylko na czynny udział primipili w rozwiązywaniu powstałego problemu, ale też na popełniony rzekomo przez Sabinusa błąd polegający na daniu żołnierzom do zrozumienia, że sytuacja jest groźna, a mimo to dowództwo ma problemy z opracowaniem jednolitego modelu postępowania ${ }^{65}$. We współczesnych publikacjach poświęconych dowodzeniu i psychologii wojskowej wskazuje się takie zachowanie jako przykład wyjątkowo negatywnego oddziaływania na morale podwładnych ${ }^{66}$. Centurionowie

${ }^{63}$ J. Harmand, L'armée..., s. 337-338; A.K. Goldsworthy, The Roman Army..., s. 15, 131-133; P.D. Johnston, The Military "Consilium" in Republican Rome, Piscataway 2008, s. 12. Fakt ten zazwyczaj tłumaczy się koniecznością delegacji zadań w kontekście nadchodzącej bitwy, ale wydaje się, że nie wyczerpuje to pełnego spektrum problemu.

${ }^{64}$ Caes., Bell. Gall. 5.28.2-4, 30.1-2, 31.1-4: „Itaque ad consilium rem deferunt magnaque inter eos exsistit controversia. Lucius Aurunculeius compluresque tribuni militum et primorum ordinum centuriones nihil temere agendum neque ex hibernis iniussu Caesaris discedendum existimabant; [...]. Hac in utramque partem disputatione habita, cum a Cotta primisque ordinibus acriter resisteretur, [...] Sabinus, et id clariore voce, ut magna pars militum exaudiret; [...]. Consurgitur ex consilio; comprehendunt utrumque et orant, ne sua dissensione et pertinacia rem in summum periculum deducant: [...]. Tandem dat Cotta permotus manus".

${ }^{65}$ Pytaniem otwartym musi bowiem pozostać, czy Cezar nie starał się aby obarczyć go główną odpowiedzialnością za poniesioną porażkę.

${ }^{66}$ S.L.A. Marshall, Men against Fire..., s. 115; R. Holmes, Acts of War..., s. 340. 
zostali przedstawieni przez Cezara jako ci, którzy potrafili zachować zimną krew w obliczu niepewnej sytuacji, przeciwstawiając się podjętej pod wpływem emocji decyzji Sabinusa - dobrze koresponduje to $\mathrm{z}$ wizerunkiem tej kategorii żołnierzy uwiecznionym przez Polibiusza ${ }^{67}$.

Wobec charakteru obowiązków ciążących na centurionach awans na to stanowisko odbywał się przede wszystkim w oparciu o doświadczenie i dokonania bojowe, co czyniło z nich naturalną elitę armii ${ }^{68}$. Przyjęcie takiego kryterium okazywało się czasem problematyczne już po zakończeniu kampanii, o czym mogą świadczyć przypadki dużej brutalności centurionów, którzy nie potrafili realizować powierzonych im zadań poza polem bitwy ${ }^{69}$. Najbardziej drastycznym przykładem sadysty (odnoszącym się do okresu cesarstwa) był niejaki Lucilius noszący przydomek Cedo alteram, czyli „Podaj kolejną”, gdyż zwykł wydawać taki rozkaz, gdy złamał rózgę na grzbiecie chłostanego żołnierza ${ }^{70}$.

W związku z tym odnosi się nieodparte wrażenie, że znaczenie centurionów podczas walki ściśle korespondowało $\mathrm{z}$ warunkami pełnionej przez nich służby. Wszystko to składa się na obraz potwierdzający choćby w ogólnych zarysach wymowę opisów Cezara. Jeżeli odpowiedzią na zawarte w tytule pytanie jest więc: „elita legionów”, to wciąż nie stanowi to wyjaśnienia, dlaczego Cezar tak silnie eksponował znaczenie centurionów, choć nie czynił tego nikt przed nim, a i w późniejszych latach nie znajdował w tym zbyt wielu naśladowców.

\section{Cele przyświecające Cezarowi}

W momencie wybuchu wojny domowej w 49 roku centurionowie okazali zdecydowane poparcie swojemu wodzowi. Nie tylko udzielili mu pożyczki na wypłatę

\footnotetext{
${ }^{67}$ Polyb. 6.24.9.

${ }^{68}$ H. Delbrück, Geschichte der Kriegskunst..., s. 515-516; J. Harmand, L'armée..., s. 328, 336-344; A.K. Goldsworthy, The Roman Army..., s. 123-124; R. Cowan, For the Glory of Rome..., s. 133; R. D’Amato, Roman Centurions 753-31 BC..., s. 11. Problem polega na tym, że zdecydowana większość informacji na temat awansowania centurionów w okresie późnej republiki pochodzi z dzieł Cezara i jego epigonów, co sprawia, że zrekonstruowane mechanizmy mogły odnosić się przede wszystkim do jego armii, inni zaś wodzowie mogli premiować - w zależności od potrzeby przymioty innego rodzaju. Jest to jednak logiczny system promocji w warunkach trwania wojny, podczas której poszukuje się naturalnych liderów, budzących zaufanie i szacunek towarzyszy broni (R. Holmes, Acts of War..., s. 340).

${ }^{69}$ Zob. M.N. Faszcza, "Cedo alteram”, or the problem with some Augustan centurions in times of peace, „Eos” 2020, 107/1-2, s. 109-125.

${ }_{70}$ Tac., Ann. 1.23.2-3.
} 
zaległego żołdu ${ }^{71}$, czy - jak chce Myles McDonnell - przekupienie żołnierzy ${ }^{72}$, lecz także wystawili własnym sumptem oddział jazdy, uważając że liczba konnicy wchodzącej w skład armii Cezara jest dalece niewystarczająca ${ }^{73}$. Dowodzi to silnego związku setników ze swoim wodzem, będącego efektem kilkuletnich starań Cezara, aby na różne sposoby zdobyć przychylność i zaufanie żołnierzy. Centurionowie byli o tyle ważną grupą, że stanowili ówcześnie „kościec legionów”, doświadczenia zaś Lucjusza Korneliusza Sulli z 88 roku wskazywały, że trzeba było liczyć się z możliwością odstąpienia oficerów wywodzących się z nobilitas bądź ściśle z nimi związanych ${ }^{74}$. Wprawdzie trudno sobie wyobrazić prowadzenie jakiejkolwiek wojny jedynie przy użyciu średniej kadry dowódczej, niemniej postawa centurionów była decydująca z punktu widzenia nastrojów podległych im oddziałów - publiczny akt aprobaty wyrażony dla planów politycznych Cezara w postaci udzielenia mu pożyczki i wystawienia oddziału jazdy był najpewniej, poza względami czysto praktycznymi, obliczony na uzyskanie właśnie takiego efektu ${ }^{75}$.

W związku z tym pojawiły się interpretacje, że eksponowanie zasług bojowych centurionów miało służyć wykreowaniu exempla służących kształtowaniu pożądanych postaw wśród żołnierzy i przyszłych rekrutów ${ }^{76}$. Takie stanowisko budzi poważne wątpliwości, wiąże się bowiem z przyjęciem założenia, że legioniści mieli stanowić w zamyśle Cezara jedną z głównych grup odbiorców Commentarii. Niewątpliwie dążył on do wyeksponowania animus i virtus swoich żołnierzy, choćby na zasadzie kontrastu z cechami przypisywanymi przeciwnikom, ale w tym wypadku chodziło o uwypuklenie atrybutów tradycyjnie kojarzonych z Romanitas i uporządkowanie ich w ramach przyjętej struktury narracyjnej ${ }^{77}$. Nadanie centurionom szczególnego znaczenia w toku narracji nie było do tego niezbędne.

71 Caes., Bell. civ. 1.39.4.

72 M. McDonnell, Borrowing to Bribe Soldiers: Caesar's “De Bello Civili” 1.39, „Hermes” 1990, $118 / 1$, s. $55-66$.

73 Suet., Jul. 68.1.

74 App., Bell. civ. 1.57.253.

75 J. Vogt, Caesar und seine Soldaten, „Neue Jahrbücher für Antike und deutsche Bildung” 1940, 3, s. 123-125, 130-131; L. de Blois, Sueton, Aug. 46 und die Manipulation des mittleren Militärskader als politisches Instrument, „Historia” 1994, 43/3, s. 332-335; Idem, Army and Society in the Late Roman Republic, w: Kaiser, Heer und Gesellschaft in der Römischen Kaiserzeit, hrsg. G. Alföldy, B. Dobson, W. Eck, Stuttgart 2000, s. 14-25; Idem, Army and General in the Late Roman Republic, w: A Companion to the Roman Army, ed. P. Erdkamp, Malden-Oxford-Carlton 2007, s. 167-169.

76 J.J. Palao Vincente, "Virtus Centurionis"..., s. 194-204; D. Nolan, Caesar's "Exempla”..., s. $34-35,42-53$.

77 F.-H. Mutschler, Erzähstil und Propaganda in Caesars Kommentarien, Heidelberg 1975, s. 196-198; J.E. Lendon, The Rhetoric of Combat..., s. 273-329; R.D. Brown, Two Caesarian Battle-Descriptions: A Study in Contrast, „The Classical Journal” 1999, 94/4, s. 329-357; A.M. Riggsby, Caesar in Gaul and Rome: War in Words, Austin 2006, s. 83-100; L. Grillo, Caesarian Intertextualities: Cotta and Sabinus in BG 5.26-37, „The Classical Journal” 2016, 111/3, s. 257-279. 
Skłaniałbym się raczej do innego wniosku, a mianowicie potraktowania zabiegu literackiego Cezara jako jednej z form zyskania sobie poparcia tej kategorii żołnierzy w obliczu zbliżającej się wojny domowej oraz podczas jej trwania. Taka interpretacja wymagałaby jednak potwierdzenia dwóch założeń. Po pierwsze, publikacji przynajmniej początkowych ksiąg Commentarii de bello Gallico i Commentarii de bello civili odpowiednio: przed rozpoczęciem konfliktu i w jego początkowym etapie. Po drugie, upowszechniania treści obu dzieł wśród ogółu obywateli rzymskich, w szczególności zaś warstw społecznych, z których wywodzili się centurionowie i wśród których po zakończeniu służby wojskowej mogliby cieszyć się poważaniem.

Zważywszy na pogłębianie się w I wieku napięć politycznych w Rzymie, próba zaskarbienia sobie oddania naturalnych liderów środowiska żołnierskiego byłaby ze wszech miar logicznym posunięciem, nawet jeśli Cezar nie od razu przewidywał wybuch wojny domowej. Podobne działania prowadzili wcześniej Sulla ${ }^{78}$ i Gnejusz Pompejusz Wielki ${ }^{79}$. Odpowiednie stylizowanie opisów byłoby więc rozszerzeniem zakresu środków zmierzających do umocnienia pozycji politycznej w oparciu o aktualny potencjał militarny, czy — pisząc wprost - armię gotową zaangażować się w konflikt zbrojny o charakterze wewnętrznym.

Problem powstania i upublicznienia poszczególnych ksiąg Commentarii od dawna budzi gorące dyskusje wśród badaczy, niemniej panuje konsensus co do tego, że skuteczność zabiegów propagandowych i kreacyjnych Cezara była uzależniona od zachowania regularnej interakcji z odbiorcami. Nawet jeśli dynamika działań politycznych i militarnych negatywnie wpływała na rozpowszechnianie kolejnych części dzieł Cezara, to w gruncie rzeczy ma to drugorzędne znaczenie, z punktu widzenia analizy treści bowiem kluczowa jest intencja bieżącego opisywania zdarzeń i wpływania na świadomość czytelników/słuchaczy. Ta zaś, wziąwszy pod uwagę treść Commentarii i wielość pojawiających się nawiązań do bieżącej sytuacji politycznej, pozostaje w zasadzie bezsporna ${ }^{80}$.

${ }^{78}$ Sall., Cat. 37.6; Oros. 5.21.3.

${ }^{79}$ Plut., Pomp. 33.5; App., Mithr. 104.490.

${ }^{80}$ Klasycznymi publikacjami poświęconymi bieżącym elementom propagandowym zawartym w dziełach Cezara są: C.E. Stevens, The "Bellum Gallicum” as a Work of Propaganda, „Latomus” 1952, 11, s. 3-18, 165-179; M. Rambaud, L'Art de la déformation...; J.H. Collins, On the Date and Interpretation of the "Bellum Civile". „The American Journal of Philology" 1959, 80/2, s. 113-132; Idem, Caesar as Political Propagandist, w: Aufstieg und Niedergang der römischen Welt, I.1, hrsg. H. Temporini, Berlin-New York 1972, s. 922-966. Problematyka ta była również eksploatowana przez kolejne pokolenia badaczy, przykładowo: T.P. Wiseman, The publication of "De Bello Gallico", w: Julius Caesar as Artful Reporter, eds. K. Welch, A. Powell, Swansea 1998, s. 1-43; K. Raaflaub, Caesar the Liberator? Factional politics, civil war, and ideology, w: Caesar against Liberty? Perspectives on his Autocracy, eds. F. Cairns, E. Fantham, Cambridge 2003, s. 35-67; W.B. Batstone, C. Damon, Caesar's Civil War, Oxford 2008, s. 18-27, 33-84; K. Raaflaub, Between Tradition and Innovation: Shifts in Caesar's Political Propaganda and Self-Presentation, w: Cesare: precursore o visionario? Atti del convegno internazionale Cividale del Friuli, 17-19 settembre 2009, cur. G. Urso, Pisa 2010, 
Należy założyć, że większość obywateli republiki, ze szczególnym uwzględnieniem mieszkańców stolicy, nie dysponowała ani czasem, ani środkami umożliwiającymi lekturę kolportowanych kopii cezariańskich dzieł. Główną formą propagowania zawartej w nich treści mogły zatem być publiczne odczyty fragmentów, pozwalające zapoznać się z „informacjami z frontu” nawet osobom niepiśmiennym ${ }^{81}$.

Intrygujące, że między Rzymem a obozem Cezara regularnie kursowali posłańcy, przewożąc przede wszystkim korespondencję adresowaną do czołowych polityków i ich ewentualne odpowiedzi ${ }^{82}$. Osobą szczególnie zaangażowaną w prowadzenie kancelarii był Caius Oppius, często bywający w stolicy i utrzymujący kontakty m.in. z Markiem Tulliuszem Cyceronem ${ }^{83}$. Nic nie stało zatem na przeszkodzie, aby kolportować „biuletyny” zawierające poszczególne księgi, względnie parafrazę corocznych sprawozdań wysyłanych do senatu. Istnienie takich „biuletynów” u schyłku republiki jest dobrze poświadczone ${ }^{84}$. Co więcej, w korespondencji Cycerona zachowała się kluczowa wzmianka z punktu widzenia rozstrzygnięcia problemu: otóż jeden z cezariańskich kurierów miał przywieźć do Rzymu właśnie paczkę zawierającą takie „biuletyny” ${ }^{25}$. Wprawdzie nie znamy jej dalszych losów, ale w świetle tej informacji nie ulega wątpliwości, że Cezar i jego współpracownicy dbali o to, aby pewna liczba odpisów nieodpłatnie trafiała do odbiorców. Na tej podstawie można domniemywać, że niektóre z nich mogły być odczytywane publicznie, a jeśli tak, to pochwały zawarte pod adresem centurionów stosunkowo szybko mogły dotrzeć do uszu ich krewnych, sąsiadów i krajanów.

Taki wniosek koresponduje ze zwięzłą formą literacką i językiem używanym przez Cezara. Christopher B. Krebs podejrzewał, że mogła być ona obliczona na dotarcie do jak najszerszego grona odbiorców, również tych niewykształconych ${ }^{86}$. Jest to o tyle prawdopodobne, że narracja Cezara ma charakter wielowarstwowy, oszczędność środków wyrazu zaś nie przekłada się na uproszczenie fabuły, którą można odczytywać na kilku poziomach. Gdyby jednak zadać pytanie, czy istniały możliwości dotarcia do osób, na których opinii mogło zależeć centurionom po zakończeniu służby wojskowej, to zarówno sposób konstruowania przekazu, jak

s. 141-157; L. Grillo, The Art of Caesar's "Bellum Civile": Literature, Ideology, and Community, Cambridge 2012; Ch.B. Krebs, More Than Words. The "Commentarii" in Their Propagandistic Context, w: The Cambridge Companion to the Writings of Julius Caesar, eds. L. Grillo, Ch.B. Krebs, Cambridge 2018, s. 29-42.

${ }^{81}$ Zob. N. Horsfall, The Culture of the Roman Plebs, London 2003, s. 48-53.

${ }^{82}$ Cic., QFr. 2.11.4, 2.13.3, 3.1.8. Kluczową publikacją poświęconą twórczości epistolograficznej Cezara jest: J. Osgood, The Pen and the Sword: Writing and Conquest in Caesar's Gaul, „Classical Antiquity" 2009, 28/2, s. 328-358.

${ }^{83}$ Cic., Att. 4.16.8, 5.1.2; QFr. 3.1.8, 3.1.10, 3.1.13, 3.1.18.

${ }^{84}$ Cic., Fam. 5.8.3, 8.1.1; QFr. 3.1.10.

${ }^{85}$ Cic., QFr. 3.1.8, 3.1.13.

${ }^{86}$ Ch.B. Krebs, More Than Words..., s. 41. 
i dostępność cezariańskiej narracji nie stały temu na przeszkodzie, co stanowiło tradycyjną barierę w przypadku rzymskiego piśmiennictwa. Nowatorstwo treści szło więc w parze z nowatorstwem formy.

Wytłumaczeniem fenomenu Cezara nie jest w tym przypadku ścisła zależność od dostępnych źródeł, które wprawdzie mogły wyznaczać ogólne ramy treści, lecz jego warsztat pisarski i zakorzenienie kulturowe po prostu wykluczały prawdopodobieństwo prostego kompilowania dostarczanych relacji. Z pewnością ułatwieniem było zdobyte przez niego doświadczenie militarne, bezpośrednie uczestnictwo w części opisywanych wydarzeń i prawdopodobny dostęp do, jak już wcześniej wspomniano, raportów i dzienników działań bojowych mogących zawierać m.in. nazwiska wyróżnionych żołnierzy i uzasadnienia wniosków o przyznanie awansów/ nagród. Zważywszy na okoliczność awansowania centurionów głównie na podstawie zasług bojowych, wydaje się naturalne, że to właśnie oni najczęściej widnieli $\mathrm{w}$ dokumentacji wykorzystywanej w toku pisania Commentarii. Caius Asinius Pollio zarzucał Cezarowi brak dokładności spowodowany m.in. zbytnim poleganiem na raportach składanych przez oficerów ${ }^{87}$. Musiały zatem odgrywać pewną, choćby nawet ograniczoną rolę w procesie kreowania wizerunków literackich.

Pozostaje pytanie, dlaczego żaden z późniejszych autorów nie poszedł w ślady Cezara? Jako pierwszą przyczynę trzeba wymienić zmianę ustroju, która w krótkim czasie wyeliminowała możliwość wzorowania się na Cezarze przez inną osobę niż cesarz. Drugim aspektem był charakter konfliktów toczonych w latach 44-30, w których przeważały wojny domowe, niesprzyjające pracy literackiej i kolportażowi dzieł pisanych na bieżąco. Na koniec wreszcie można odnieść wrażenie, że jedynym wodzem posiadającym dostateczną charyzmę i poparcie w szeregach wojska był Antoniusz, on zaś nie przejął od niedawnego zwierzchnika talentu pisarskiego i zamiłowania do twórczości literackiej.

Bibliografia

Ardant du Picq [Ch.], Études sur le combat, Paris 1880.

Batstone W.B., Damon C., Caesar's Civil War, Oxford 2008.

Bell M.J.V., Tactical Reform of the Roman Republican Army, „Historia” 1965, 14/4, s. 404-422.

de Blois L., Sueton, Aug. 46 und die Manipulation des mittleren Militärskader als politisches Instrument, „Historia” 1994, 43/3, s. 324-345.

de Blois L., Army and Society in the Late Roman Republic, w: Kaiser, Heer und Gesellschaft in der Römischen Kaiserzeit, hrsg. G. Alföldy, B. Dobson, W. Eck, Stuttgart 2000, s. 11-30.

de Blois L., Army and General in the Late Roman Republic, w: A Companion to the Roman Army, ed. P. Erdkamp, Malden-Oxford-Carlton 2007, s. 164-179.

\footnotetext{
${ }^{87}$ Suet., Jul. 56.4 .
} 
Brand C.E., Roman Military Law, Austin 1968.

Brice L.L., Discharging Pullo and Vorenus: Veterans in Rome, w: Rome, Season Two: Trial and Triumph, ed. M.S. Cyrino, Edinburgh 2015, s. 25-35.

Brown R.D., Two Caesarian Battle-Descriptions: A Study in Contrast, „The Classical Journal” 1999, 94/4, s. 329-357.

Brown R., "Virtus consili expers": An Interpretation of the Centurions' Contest in Caesar, De bello Gallico 5, 44, „Hermes” 2004, 132, s. 292-308.

Collins J.H., On the Date and Interpretation of the "Bellum Civile", „The American Journal of Philology" 1959, 80/2, s. 113-132.

Collins J.H., Caesar as Political Propagandist, w: Aufstieg und Niedergang der römischen Welt, I.1, hrsg. H. Temporini, Berlin-New York 1972, s. 922-966.

Cowan R., For the Glory of Rome: A History of Warriors and Warfare, London 2007.

Cowan R., The Real Pullo and Vorenus, „Ancient Warfare” 2007, 1/2, s. 25-28.

D'Amato R., Roman Centurions 753-31 BC: The Kingdom and the Age of Consuls, Oxford 2011.

D'Amato R., Roman Centurions 31 BC-AD 500: The Classical and Late Empire, Oxford 2012.

Delbrück H., Geschichte der Kriegskunst im Rahmen der politischen Geschichte, I, Das Altertum, 3. Auflage, Berlin 1920.

Eisenhut W., „Virtus Romana“: ihre Stellung im römischen Wertsystem, München 1973.

Faszcza M.N., „Vitis centurionis”, czyli o okolicznościach nadania centurionom symbolu ich rangi, „Przegląd Historyczno-Wojskowy" 2015, 2, s. 7-20.

Faszcza M.N., Wyobrażenia późnorepublikańskich centurionów i ich znaczenie dla badań nad wojskowością rzymska w I w. przed Chr., „Res Historica” 2015, 40, s. 11-40.

Faszcza M.N., Wzrost dyscyplinarnych uprawnień centurionów w I w. p.n.e., w: Armia, systemy obronne i ideologiczno-religijne aspekty wojny w imperium rzymskim, red. H. Kowalski, P. Madejski, Lublin 2015, s. 11-25.

Faszcza M.N., “Cedo alteram”, or the problem with some Augustan centurions in times of peace, „Eos” 2020, 107/1-2, s. 109-125.

Franzoni C., Il monumento funerario patavino di un militare e un aspetto dei rapporti artistici tra zone provinciali, „Rivista di Archeologia” 1982, 6, s. 47-51.

Franzoni C., "Habitvs atqve habitvdo militis". Monumenti funerari di militari nella Cisalpina Romana, Roma 1987.

Gabba E., Republican Rome, the Army \& the Allies, trans. P.J. Cuff, Oxford 1976.

Gelzer M., The Roman Nobility, trans. R. Seager, New York 1969.

Goldsworthy A.K., The Roman Army at War 100 BC-AD 200, Oxford 1996.

Grillo L., The Art of Caesar's "Bellum Civile": Literature, Ideology, and Community, Cambridge 2012.

Grillo L., Caesarian Intertextualities: Cotta and Sabinus in BG 5.26-37, „The Classical Journal” 2016, $111 / 3$, s. 257-279.

Grossman D., O zabijaniu. Psychologiczny koszt kształtowania gotowości do zabijania w czasach wojny i pokoju, przeł. D. Konowrocka, Warszawa 2010.

Harmand J., L’armée et le soldat à Rome: de 107 à 50 avant notre ère, Paris 1967.

Harris W.V., War and Imperialism in Republican Rome 327-70 BC, Oxford 1979.

Holmes R., Acts of War: the Behaviour of Men in Battle, $2^{\text {nd }}$ edition, London 2003.

Horn Th., Sextius Baculus, „Greece \& Rome” 1961, 8/2, s. 180-183.

Horsfall N., The Culture of the Roman Plebs, London 2003.

Johnston P.D., The Military Consilium in Republican Rome, Piscataway 2008.

Keegan J., The Face of Battle, New York 1976.

Keppie L., Colonisation and Veteran Settlement in Italy, 47-14 BC, Rome 1983.

Keppie L., The Making of the Roman Army: From Republic to Empire, London 1984. 
Keppie L., A centurion of "legio Martia” at Padua?, „Journal of Roman Military Equipment Studies" 1991, 2, s. 115-121.

Konieczny S., Strach i odwaga w działaniach bojowych, Warszawa 1964.

Krebs Ch.B., More Than Words. The "Commentarii" in Their Propagandistic Context, w: The Cambridge Companion to the Writings of Julius Caesar, eds. L. Grillo, Ch.B. Krebs, Cambridge 2018, s. $29-42$.

Lee A.D., Morale and the Roman Experience of Battle, w: Battle in Antiquity, ed. A.B. Lloyd, Swansea 1996, s. 199-217.

Lendon J.E., The Rhetoric of Combat: Greek Military Theory and Roman Culture in Julius Caesar's Battle Descriptions, „Classical Antiquity” 1999, 18/2, s. 273-329.

Lendon J.E., Soldiers \& Ghosts: A History of Battle in Classical Antiquity, New Haven-London 2005.

Levene D.S., Livy on the Hannibalic War, Oxford 2010.

Luce T.J., Livy: The Composition of His History, Princeton 1977.

McDonnell M., Borrowing to Bribe Soldiers: Caesar's “De Bello Civili” 1.39, „Hermes” 1990, 118/1, s. $55-66$.

McDonnell M., Roman Manliness: "Virtus" and the Roman Republic, Cambridge 2006.

Marshall S.L.A., Men against Fire: The Problem of Battle Command, $2^{\text {nd }}$ edition, Norman 2000.

Maxfield V.A., The Military Decorations of the Roman Army, Berkeley-Los Angeles 1981.

Moran Lord, The Anatomy of Courage, $2^{\text {nd }}$ edition, London 1966.

Murray L., Psychologia wojny. Strach i odwaga na polu bitwy, przeł. E. Zajbt, Warszawa 2014.

Mutschler F.-H., Erzähstil und Propaganda in Caesars Kommentarien, Heidelberg 1975.

Nolan D., Caesar's "Exempla" and the Role of Centurions in Battle, w: "Circum Mare": Themes in Ancient Warfare, ed. J. Armstrong, Leiden-Boston 2016, s. 34-62.

Oakley S.P., Single Combat in the Roman Republic, „The Classical Quarterly” 1985, 35/2, s. 392-410.

Osgood J., The Pen and the Sword: Writing and Conquest in Caesar's Gaul, „Classical Antiquity” 2009, 28/2, s. 328-358.

Palao Vincente J.J., "Virtus Centurionis”. La figura del centurión en César, „Gerión” 2009, 27/1, s. $191-206$.

Parker H.M.D., A Note on the Promotion of the Centurions, „The Journal of Roman Studies” 1926, 16, s. $45-52$.

Parker H.M.D., The Roman Legions, $2^{\text {nd }}$ edition, New York 1958.

Perrin B., The Crastinus Episode at Palaepharsalus, „Transactions of the American Philological Association" 1884,15 , s. $46-57$.

Raaflaub K., Caesar the Liberator? Factional politics, civil war, and ideology, w: Caesar against Liberty? Perspectives on his Autocracy, eds. F. Cairns, E. Fantham, Cambridge 2003, s. 35-67.

Raaflaub K., Between Tradition and Innovation: Shifts in Caesar's Political Propaganda and Self-Presentation, w: Cesare: precursore o visionario? Atti del convegno internazionale Cividale del Friuli, 17-19 settembre 2009, cur. G. Urso, Pisa 2010, s. 141-157.

Radin M., The Promotion of Centurions in Caesar's Army, „The Classical Journal” 1915, 10/7, s. 300311.

Rambaud M., L’Art de la déformation historique dans les Commentaires de César, Paris 1953.

Resch K., „Omnibus centurionibus occisis“ - Überlegungen zu relativen Verlustzahlen bei Caesar, „Historia” 2010, 59/1, s. 122-127.

Riggsby A.M., Caesar in Gaul and Rome: War in Words, Austin 2006.

Sabin P., The Face of Roman Battle, „The Journal of Roman Studies” 2000, 90, s. 1-17.

Smith Ch.S., “Centurio Romanus": “A First-Class Fightin' Man”, „The Classical Weekly” 1928, 22/3, s. $17-22$. 
Speidel M.P., The framework of an Imperial legion. The fifth annual Caerleon lecture in honorem Aquilae Legionis II Augustae, Cardiff 1992.

Steinwender Th., Zur Kohortentaktik, „Rheinisches Museum für Philologie” 1915, 70, s. 416-440.

Stevens C.E., The “Bellum Gallicum” as a Work of Propaganda, „Latomus” 1952, 11, s. 3-18, 165-179.

Suolahti J., The Junior Officers of the Roman Army in the Republican Period: A Study on Social Structure, Helsinki 1955.

Syme R., The Roman Revolution, Oxford 1939.

Taylor M.J., Tactical Reform in the Late Roman Republic: The View from Italy, „Historia” 2019, 68/1, s. $76-94$.

Veith G., Die Taktik der Kohortenlegion, „Klio” 1907, 7, s. 303-334.

Vogt J., Caesar und seine Soldaten, „Neue Jahrbücher für Antike und deutsche Bildung” 1940, 3, s. $120-135$.

Walsh P.G., Livy: His Historical Aims and Methods, Cambridge 1961.

Wegeleben Th., Die Rangordnung die römischen Centurionen, Berlin 1913.

Welch K., Caesar and his officers in the Gallic War Commentaries, w: Julius Caesar as Artful Reporter, eds. K. Welch, A. Powell, Swansea 1998, s. 85-110.

Wiedemann T., Singe Combat and being Roman, „Ancient Society” 1996, 27, s. 91-103.

Wiseman T.P., The publication of "De Bello Gallico", w: Julius Caesar as Artful Reporter, eds. K. Welch, A. Powell, Swansea 1998, s. 1-43.

Michał Norbert Faszcza

Caesar's Centurions: the Elite of the Legions or Literary Fiction?

Summary

One of the distinctive features of Caesar's narrative about wars was the praise he bestowed on the merits of his centurions. The question arises why he promoted this category of soldiers and whether source analysis confirms the plausibility of their combat achievements. Michał Norbert Faszcza has collected and examined the relevant information contained in the extant written sources in an attempt not only to find confirmation of Caesar's claims in the context of the growing importance of the centurions in the $1^{\text {st }}$ century BCE, but also to ponder the reason for Caesar's use this type of literary device. The centurions are a genuine symbol of Caesar's army, and therefore this theme is of key importance for the reconstruction of the internal relations in his legions.

Key words: Caesar, centurions, Roman army, Roman Republic 